\title{
Is high employment in the eurozone possible? Some reflections on the institutional structure of the eurozone and its crisis
}

\author{
Mario Seccareccia* \\ Full Professor, Department of Economics, University of Ottawa, ON, Canada
}

\begin{abstract}
The paper analyses some well-known explanations of the eurozone crisis and seeks to provide an answer to the question of whether expansionary fiscal policy is feasible within the restrictive confines of the existing structure of the eurozone. The paper addresses this question by focusing on a very precise historical period, 2008-2009, which immediately followed the global financial crisis and the ensuing Great Recession, to understand what permitted such a sharp rise in government spending throughout the eurozone without triggering a sovereign debt crisis until early 2010.
\end{abstract}

Keywords: eurozone crisis, fiscal policy, institutional adaptation

JEL codes: E52, E58, E62, E63

\section{INTRODUCTION}

Many economists have written about the eurozone crisis and the broad consensus has been that it began sometime in early 2010 when the Greek drama began to unfold (Baldwin/ Giavazzi 2015). This crisis remains virtually unprecedented in the economic history of Western Europe over the last seven decades since the end of World War II, because it brought widespread deflation as well as levels of mass unemployment to some European countries not witnessed perhaps since the Great Depression. The global financial crisis of 2007-2008 (starting with the US subprime crisis) had preceded the eurozone crisis by at least two years. However, contrary to the official discourse that the former crisis 'led to' or caused the latter (see European Commission 2017: 6), I wish to argue in this article that the worldwide financial crisis was neither the proximate cause, nor perhaps even the

* The author is Full Professor, Department of Economics, University of Ottawa, Ottawa, Ontario, Canada K1N 6N5. The ideas discussed in this paper were first presented and debated at a conference on 'Full Employment in Europe: With or Without the Euro?' at the University of Grenoble, in Grenoble, France, on 16 May 2014. The author presented the current version at the CEPN, University of Paris 13, Villetaneuse, France, on 6 June 2017. The author wishes to thank Cristiano Duarte, Dany Lang, Marc Lavoie, Wesley Marshall, Alain Parguez, Pascal Petit, and two anonymous referees for their helpful comments. He also wishes to acknowledge the important financial support provided by the Institute for New Economic Thinking (INET), the Centre for International Governance and Innovation (CIGI), and the Social Sciences and Humanities Research Council of Canada (SSHRC) for the project: 'The Political Economy of the New Fiscalism,' and for the excellent technical assistance from Drew Penner and Omar Abdikader in collecting the data.

Received 24 May 2017, accepted 27 August 2017 
triggering mechanism of the eurozone regional crisis. Since 2010, the European continent embarked on a rollercoaster ride that for a while seemed to be heading out of control by bringing economic and social devastation as well as political turmoil along its path. While these instabilities have somewhat diminished in recent years, this has not happened because of the initial lending provisions and bail-out conditions enforced by the so-called troika (the European Commission, the European Central Bank (ECB), and the International Monetary Fund (IMF)). Some of these provisions were almost in the nature of Ponzi financing schemes imposed on some of the most vulnerable recipient member states of the European Economic and Monetary Union (EMU), such as Greece. The easing of the initial instabilities was primarily the result of other important actions by the ECB in redefining somewhat its own role. Indeed, these latter central-bank actions, which some have argued have made the ECB itself a sort of fiscal arbiter of last resort (Auerback 2010/2011), have provided indirectly more latitude for fiscal policy measures, particularly through its recent activities of quantitative easing $(\mathrm{QE})$ with its large-scale purchases of European government securities in the secondary sovereign bond market.

The purpose of this article is to provide an answer to a simple question. If European policymakers wanted to achieve a high level of employment, would it be possible to reach this goal through concerted fiscal policy action that is feasible under the existing restrictive eurozone monetary and fiscal architectures? Despite the terrible consequences of the crisis on European society, this almost two-decade-old monetary structure has remained largely intact in terms of the lack of institutional integration between money and the state. The implications of that fundamental institutional separation has meant the de facto tying of the hands of national fiscal authorities to the discipline required of the domestic and international financial markets, by imposing a perverse macroeconomic policy of pro-cyclical budgetary net spending in times of crisis. Many commentators and critics of the existing architectures of the eurozone now broadly understand this 'structural design flaw' of the EMU (see, for example, Stiglitz 2014; 2016). Indeed, some authors have argued that this deflationary bias is actually not so much a 'flaw' as it is an institutional reflection of the original intent and purpose of the peculiar design of the EMU (Parguez et al. 2003; Parguez 2016).

As a corollary, one can also pose an ancillary question whose answer can perhaps help to provide an answer to the previous question. Has the perverse macro-fiscal policy response, which characterized the immediate post-2010 era, been true throughout the short life of the EMU or have there appeared exceptions to the way the financial markets have behaved in disciplining countries that seek to pursue expansionary fiscal policies? While we pose the first question prospectively about the feasibility of such an outcome, the second is retrospective in nature by asking whether it has actually been possible to conduct such policy during the history of the EMU. Though noticeably related, answering the second/retrospective question in the affirmative does not necessarily preclude the same affirmative answer to the first/prospective question. To answer these two related questions, I have chosen to engage in a certain pointilisme by inspecting closely, almost as one would with a magnifying glass, a particular historical episode going from the third quarter of 2008 to the end of 2009. The purpose of my research is to observe and understand to what extent the existing EMU structure actually prevented eurozone countries from pursuing a substantial fiscal expansion, as they became committed to some hybrid fiscal policy of functional finance. Given the international desire to combat recession through fiscal stimulus, the 2008-2009 period - the so-called 'Keynes moment' (after the 'Minsky moment' of 2007-2008) offers a unique historical litmus test. My conclusion is that, when there was a political will to do so collectively, national governments were able to increase public debt essentially in lockstep with much of the rest of world to combat the Great Recession of 
2008-2009 and, at the time, also to bail out the banking sector that had derailed in many countries. Moreover, the general acceptance (principally by the G20 leaders at the time) of the policy perspective of the 'New Fiscalism' that had hurriedly been adopted in most industrialized countries immediately after the international financial crisis of 2008 (see Seccareccia 2012) also contributed to avoid any significant negative reactions from the financial markets. Only in 2010 was there a reversal of attitude, after national governments by then had bailed out the banking sector (both inside and outside the eurozone) and after the spooking of financial markets because of the disclosure of apparently hidden and unsustainable Greek government debt levels. Starting in 2010, national governments, mainly of the so-called GIIPS countries (Greece, Ireland, Italy, Portugal, and Spain), began to accumulate explosive debts not so much because of any excessive primary deficits

but because of rising interest rates resulting from the downgrading of their government bonds in the financial markets. In fact, these countries struggled throughout this period to achieve target primary public-sector surpluses through severe fiscal austerity measures imposed at terrible cost to the entire social fabric of those regions of Europe. As we shall see, the perception and herd behavior of the financial markets (regardless of reality, known to many financial actors even before 2008) actually exacerbated the crisis for the weakest links, especially Greece.

To dispel any doubts, an important purpose of this article is, of course, not to defend the view that the eurozone institutional structure could and should be salvaged without some profound structural changes. I have argued over the years against the existing euro architectural design (Parguez et al. 2003; Seccareccia/Lequain 2006; Seccareccia/Correa 2017). The point that I wish to make is that, even under this highly constraining institutional structure, the veritable obstacle to high employment in Europe is the lack of political will on the part of the European political elites themselves. Their unfortunate behavior after 2010 was instrumental in conditioning the financial markets to react throughout the eurozone crisis in such punitive ways, particularly during the Greek saga.

\section{THE EUROZONE UNEMPLOYMENT DISASTER AND ITS CAUSES}

Rates of unemployment in Europe since the eurozone crisis have reached levels that have even surpassed the earlier postwar peaks of the 1980s and 1990s, with unemployment nowadays still probably afflicting close to a majority of the youth labor force in countries such as Greece and Spain. International forces did initially affect the GIIPS countries, especially those countries whose exports were most sensitive to US growth rates starting in 2008. However, the continued rise in unemployment and the persistence of this unemployment disaster was primarily the result of deep budget cuts and austerity policies adopted since 2010, after the banking bail-outs and the initial stimulus packages were implemented during the 2008-2009 period by most countries in the eurozone and internationally. Since then, many of these economies, primarily of the GIIPS countries, witnessed a terrible contraction in real GDP, a drop of as much as 20 percent or more for the immediate half-decade after the eurozone crisis began, as in the case of Greece. Tragically, this decline also stands out and compares in the historical annals with the scale of severe contractions in output in the Western world not witnessed internationally since the Great Depression of the 1930s.

This mass unemployment was not new in the European context, with the origins of double-digit unemployment rates beginning in the 1980s after the creation of the European Monetary System (EMS). At the time, mainstream economists often mistakenly 
attributed the high unemployment rates to supply-side labor-market factors, which was a view (the so-called 'euro-sclerosis' argument) that had been promoted by OECD economists (for a discussion and criticism, see Seccareccia/Lequain 2006). From a longer-term perspective, one can easily corroborate that the severity and sharp rise in unemployment rates over the five years following the global financial crisis was unprecedented for the post-WWII period (see Figures 1 and 2 for the post-1970 period). The unemployment rate, however, had been steadily declining in the GIIPS countries since the mid 1990s after the crisis of the European Exchange Rate Mechanism (ERM), which preceded the adoption of the euro, with the differences in unemployment rates, especially vis-à-vis Germany, decreasing before the international financial crisis. As can best be observed from Figure 2, Germany and the GIIPS countries bifurcated both before, as Germany became the 'sick man of Europe' (partly as a consequence of German reunification a decade earlier), and after, as German neo-mercantilist policy triumphed at the expense of its southern neighbors. One can best see this when regrouping these GIIPS countries by simply averaging their unemployment rates and comparing them to those of Germany (as in Figure 2).

What is clearly observable in Figure 2 is that, until just before the financial crisis, the evolution of the gaps in European unemployment rates did not presage the sharp reversal that took place primarily after the global financial crisis. There was, indeed, a short prelude a few years before the dramatic bifurcation of the series actually took shape, but this was so largely because of a more rapid decline of Germany's unemployment rate when compared to the milder trend decline of the GIIPS countries after 2005. It is during and after the financial crisis that the disastrous reversal occurred and continues to persist, despite the significant turnaround in recent years.

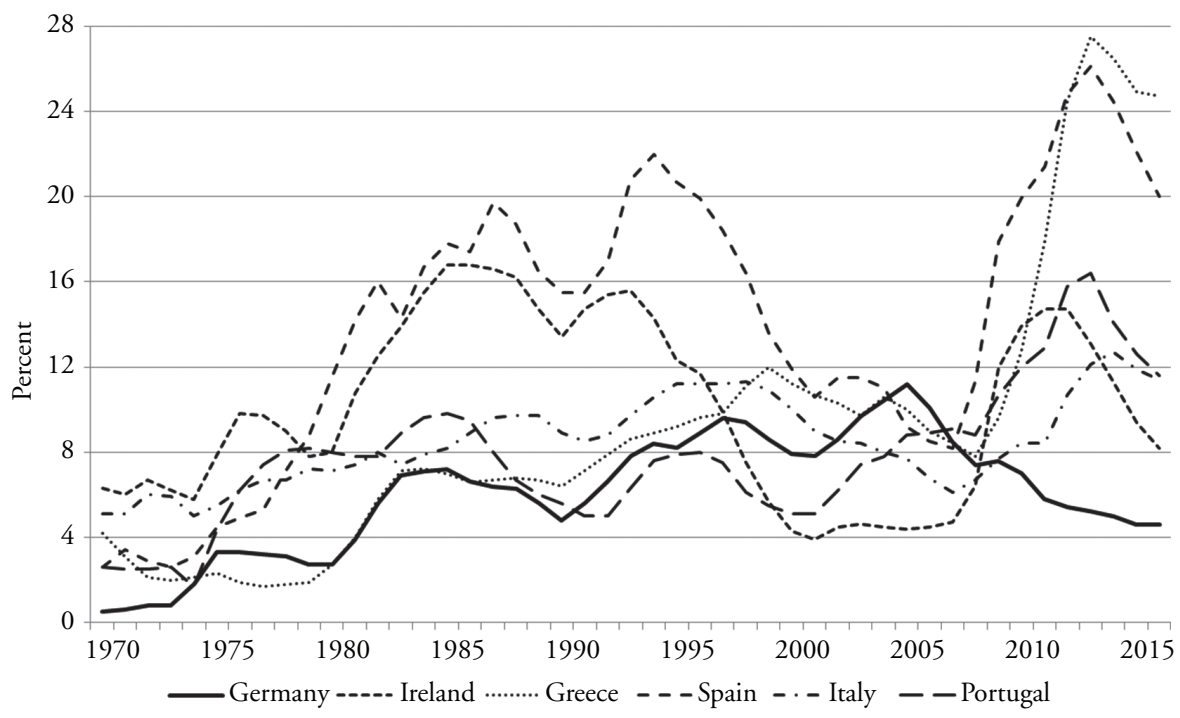

Source: AMECO (http://ec.europa.eu/economy_finance/ameco/user/serie/SelectSerie.cfm), Series Code: ZUTN

Figure 1 Evolution of unemployment rates in Europe over the last four and a half decades, 1970-2016 


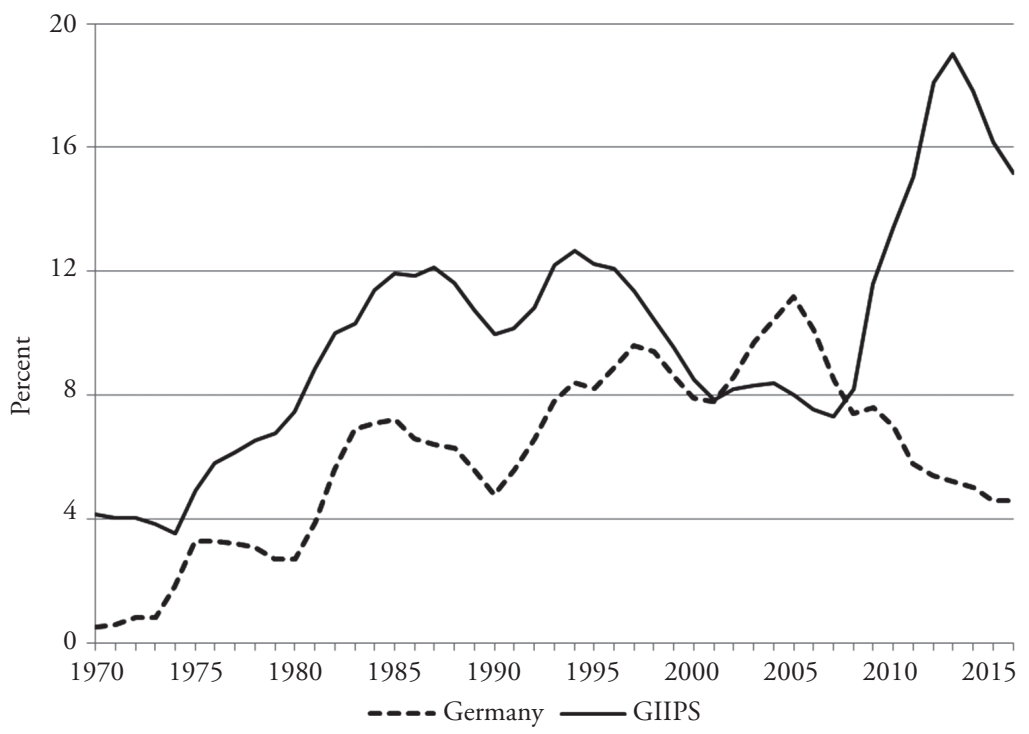

Source: AMECO (http://ec.europa.eu/economy_finance/ameco/user/serie/SelectSerie.cfm), Series Code: ZUTN.

Figure 2 Evolution of unemployment rates in Europe: Germany and average of GIIPS countries, $1970-2016$

\section{TRADITIONAL EXPLANATIONS OF THE EUROZONE CRISIS}

\subsection{Fiscal profligacy}

The most divisive of the explanations for the existence and persistence of the eurozone crisis, one that still prevails, especially among certain European policymakers, is the view that the problem is due to a lack of fiscal discipline. The latter behavior would be a cultural trait of the GIIPS countries, when compared to the austere German attribute. This argument, originally given much credence by the media and political leaders in Europe, has two sides to it. The first aspect of the profligacy story, stated usually in the form of an untestable truism, is simply the affirmation that it was the indiscipline of policymakers that resulted in reckless overspending and created the sovereign debt crisis for the GIIPS countries, as the latter governments raised public-debt ratios to unsustainable levels. Hence, feeding into the usual stereotyping, corrupt GIIPS leaders were the cause as the latter succumbed to myopic political pressures from interest groups who benefited from the excessive net spending. The second aspect of the fiscal profligacy argument is less blatant and based on a more complex Mundell-type reasoning. The latter argument is often reduced to a moral hazard problem arising from the behavior of one country in the context of a multi-country monetary union. This arises when the government of a member state acts myopically to maximize the short-run gains in the form of higher incomes for its own citizens by choosing to run excessive deficits while externalizing some of the increased costs to the remaining members of the monetary union. According to this explanation, deficit spending in one country (say, Italy) generates benefits through the usual multiplier effect for a country in terms of higher incomes domestically, but this excessive spending in one country can potentially harm one's 
neighbor (say, France). Accordingly, as long as it brings only a slight upward pressure on the interest rates of the overall monetary union because of common monetary policy and high capital mobility, the traditional neoclassical crowding-out effect that normally afflicts the domestic economy would instead be shared by the economies of the entire monetary union. This would be in the form of both marginally lower interest-sensitive private spending across the monetary union and some export crowding-out because of the incremental upward pressure that the slightly higher interest rates would also bring to the exchange rate of their single currency. Various complex forms of this externality effect, whereby benefits to one country in the form of higher domestic incomes become a loss shared by members of the monetary union as a whole, are found discussed, for example, in Carlberg (1999; $2001 ; 2006)$. Some of this reasoning is highly questionable theoretically because of its neoclassical foundations. However, it remains the focus of policy discussion and serves as an important ideological underpinning for the continued implementing of austerity measures in the GIIPS countries. In the political sphere in Europe, this fiscal profligacy argument has spurred on the adoption of the German debt brake of 2009 (Truger 2013; Hein/Truger 2014), and, since 2012, the adherence to the 'reinforced' Stability and Growth Pact (the so-called 'Fiscal Compact'), with its reaffirmation of the mandatory balanced budget rule (see Asensio 2013).

If we are to believe this story of excessive public spending, where is the evidence of this fiscal profligacy precipitating the eurozone crisis? Figure 3 displays some series of debt/ GDP ratios for a selected group of countries within the eurozone. While it is true that some countries have begun since the advent of the euro with high overhanging publicdebt ratios, namely Greece and Italy, what is most remarkable is the relative stability of these public-debt ratios, with some GIIPS countries, specifically Ireland and Spain,

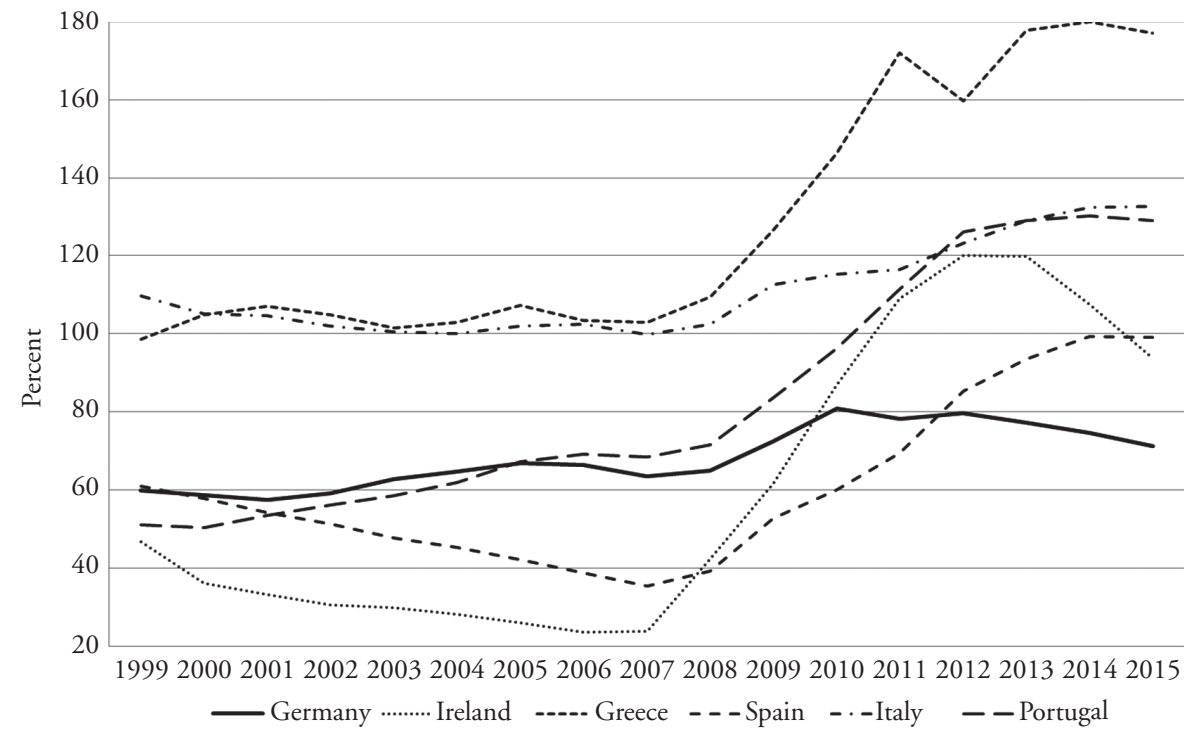

Source: AMECO (http://ec.europa.eu/economy_finance/ameco/user/serie/SelectSerie.cfm), Series Code: UDGG.

Figure 3 General government-consolidated gross debt as a percentage of GDP, selected countries of the eurozone, 1999-2015 
even running budget surpluses until 2007. Ironically, it was primarily the core countries, Germany and France, that had been running deficits until 2005-2006, as can be seen in Figure 3 for Germany where the public debt-to-GDP ratio had been rising for much of the period and actually only declined significantly again after 2012 .

Despite the persistence and relative stability of a specific structure of public-debt ratios, interest rates in the eurozone converged throughout that era before the global financial crisis (as will be analysed separately and discussed below). As these countries had adopted a single currency, the financial markets behaved as if, having now eliminated the exchange-rate risk that had generated the recurrent problems plaguing the previous fixed-exchange-rate system (the EMS) from 1979 to 1998, there was no other risk factor to contend with under a single currency. Few imagined at the time that, under the EMU structure, exchange-rate risk would merely undergo a metamorphosis and become a problem of sovereign debt risk, since everyone believed that financial market pressures on sovereign states would suffice to ensure compliance of budgetary rules. However, in practice, this is not altogether what happened.

Figure 3 also shows that something dramatic did happen in 2008-2009 to push virtually every country into public-sector deficits, with public-debt ratios rising sharply in these countries and with each following very similar trajectories until the post-2010 eurozone crisis (even in Germany and Italy where the rise was somewhat milder). There are essentially three reasons for the jump in those debt ratios during the short interval between the global financial crisis of 2008 and the eurozone crisis that began in 2010. First, as the world economy entered into a 'Great Recession' in 2008-2009 with growth rates collapsing and unemployment rates increasing concomitantly, this prompted automatic stabilizers in these countries to generate significant public-sector deficits. For a highly integrated world economy in trade and financial flows, this was simply the outcome of a worldwide shock resulting in negative growth. Using as an indicator the growth rate of private-sector debt, Figure 4 displays how this indicator for the eurozone collapsed in 2008-2009, falling to near zero or even negative values. This brought about increased upward pressure on public-sector spending, especially in the GIIPS countries which faced a steeper decline at the time. Hence, declining private debt spurred on growing public debt.

Second, and just as important, following the G20 meeting in mid November of 2008 in Washington, there was an international coordinated effort to undertake discretionary net spending in the form of fiscal stimulus packages worldwide. Much as in the rest of the world, at the time, this policy action also reverberated in the eurozone. These reactions hardly represent the misbehavior of any one group of countries engaged in some form of fiscal extravagance, but rather they seem to appear more as part of a coordinated effort to combat the severe recession resulting from the global financial crisis.

There was, however, a third reason that one may describe as being more 'home-grown' in the GIIPS countries. Not only was there higher growth in overall private-sector debt in these countries before the global financial crisis, but, moreover, many of these GIIPS countries had experienced a housing bubble from which Germany had been completely shut out during the decade prior to the global financial crisis. The convergence of interest rates among the eurozone countries (towards the lower German interest rates) together with the rising growth rates in the GIIPS countries, were accompanied by a rising trade imbalance in favor of Germany. This imbalance even attracted progressively more speculative German savings and thereby further supported the booming domestic real-estate markets of Ireland and Southern Europe (see Koo 2014). A look at the evolution of residential property values in Ireland, Greece, and Spain, as compared to Germany (see Figure 5), substantiates this discrepancy between Germany and the GIIPS countries, as the latter's banking sectors 


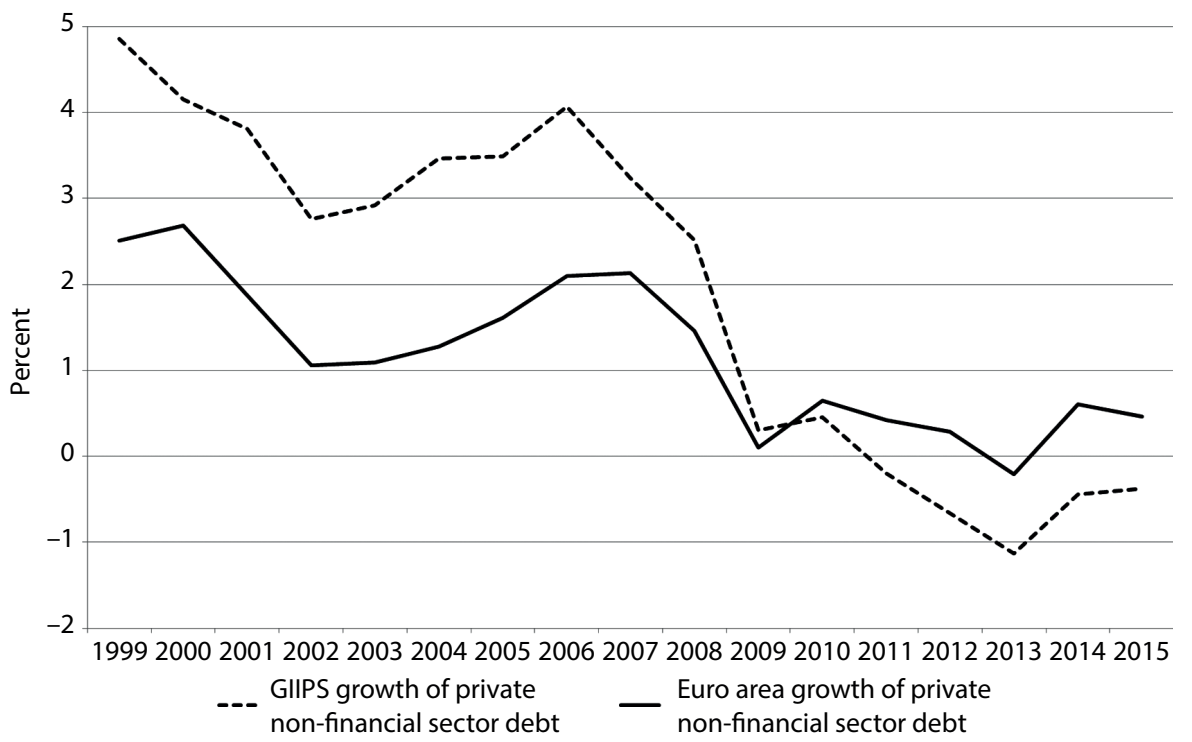

Source: BIS Total Credit Statistics, http://www.bis.org/statistics/totcredit.htm.

Figure 4 Percentage growth of private-sector debt: euro area and GIIPS average, 1999-2015

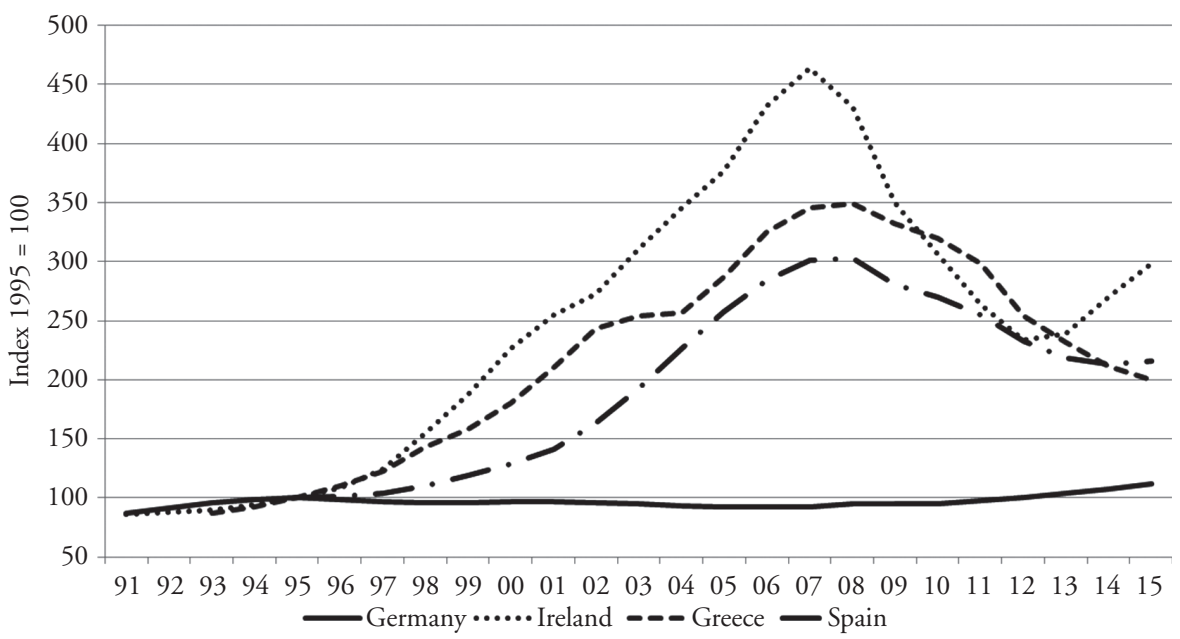

Source: BIS Residential Property Price database, http://www.bis.org/statistics/pp.htm.

Figure 5 Evolution of residential property prices in Germany versus Ireland, Greece, and Spain, 1991-2015 
succumbed to the collapse of their respective housing markets. One witnesses the transformation of private debt into sovereign debt as their domestic banks necessitated bailouts in 2008-2009.

Hence, the relative stability of public-debt ratios in the eurozone countries throughout the period prior to the global financial crisis and the proportionate rise of their public-debt ratios during the Great Recession would mean that something actually happened only after 2009 to trigger the euro crisis that was hardly the result of fiscal profligacy.

\subsection{Neo-mercantilist trade imbalances and balance-of-payments problems}

There has been much discussion over the issue of trade imbalances even among heterodox economists, with most of the criticism on the part of the latter focused on the neo-mercantilist role of Germany in the context of the eurozone. At least two versions of the competitiveness argument have appeared in the literature.

First, the mainstream narrative of this trade imbalance problem begins with the founding of the eurozone itself in 1999 as a non-optimal currency area (OCA). Based on OCA reasoning, it starts from the principle that asymmetric shocks, especially because of the global financial crisis, affected eurozone countries differently and these eventually triggered some form of twin deficits. However, these imbalances were believed to be simply part of the restructuring process until, in the long run, the underlying industrial asymmetries within the eurozone would disappear, often appealing to reasoning originally defended by Frankel/Rose (1998) on the endogeneity of the OCA adjustment process (Brodzicki 2012). However, the structure of causality now went from trade imbalances to budgetary imbalances and sovereign debt problems and not so much the other way around, as in the fiscal profligacy storyline. Other mainstream writers, such as Calmfors et al. (2012) and Sinn (2014), tend to play down the OCA argument and, instead, point to a neo-Hayekian problem of resource misallocation. For instance, Calmfors et al. (2012: 63) write:

The announcement and introduction of the euro (in a period of global undervaluation of risk) constituted a unique and strong shock to Western Europe's economy that led to extreme and unusual cross-border capital movements. In those countries subject to capital inflows, the economy underwent a growth process with sustained increases in prices and rising current account deficits. In Germany, which suffered from a capital outflow, the real economy and prices stagnated, turning its current account deficit into a surplus, as the competitiveness of exporting industries increased and imports were held back by stagnating incomes.

Hence, the adoption of the euro carried optimistic expectations about the prospects of high growth in the peripheral countries, initially by attracting savings from the core countries, which, with the elimination of exchange-rate risk, brought about in the GIIPS countries artificially low interest rates. Based on the usual neoclassical causality, the low interest rates and flows of savings from the core countries led to an investment boom in the latter countries. The high growth in the GIIPS countries eventually pushed up wages and prices in relation to those of the core countries. This inflation eroded their competitiveness and generated current-account imbalances across the eurozone and, accompanying it, budgetary imbalances. Within this logic, the solution, of course, is deflation in the GIIPS countries through the implementation of austerity policies.

The second version of this trade imbalance argument is the non-mainstream account that frames the analysis in terms of German 'monetary mercantilism' of beggaring its own workers so as to achieve a persistent trade surplus (Cesaratto/Stirati 2010/2011; Simonazzi et al. 2013; Cesaratto 2015 (in his critique of Lavoie 2015a); Cesaratto 2017). Following German reunification, by the 1990 s German firms found themselves in a favorable 
position in being able to access a vast pool of labor reserves both within the now reunited Germany and from Eastern Europe. This brought down wage growth in Germany and the German economy was for a long time 'living below its means' by pursuing a neo-mercantilist strategy of 'implicitly undervalued' commodity exports (Flassbeck/Lapavitsas 2013: 12, 17). The implications for Europe were that that this German neo-mercantilist strategy caused persistent trade imbalances that ended with a balance-of-payments crisis by 2010 .

The solution proposed by heterodox economists becomes the mirror image of the austerity solution advocated by the mainstream. Much as Keynes had argued in the 1940s (in the debates over an International Clearing Union), rather than deficit countries pursuing policies of austerity and deflation, the proposed solution is that surplus countries ought to inflate. This would entail not only a high-growth spending strategy pursued by the core countries, primarily Germany, which were on the positive side of the twin balances, but also the setting-up of a eurozone 'wage solidarity' incomes policy, for instance, referred to by Brancaccio (2012) as a 'European Wage Standard.' In focusing their proposal on Germany, with its much lower growth of wages and prices, Flassbeck/ Lapavitsas (2013: 17) argue that ' $[t]$ his is why the adjustment process has to be symmetric at least. This means that the country that is implicitly undervalued has to undertake as strong an effort towards upward adjustment, and that means faster wage increases, as the other countries undertake in terms of downward adjustment.' However, just as it took a long time to create the economic disarticulations and imbalances that began even before the adoption of the euro, they also note that such a strategy in dealing with the competitiveness problem may well take a long time to unwind.

There is much to be commended about the latter diagnosis of the problem, since it also fits very well with the view emanating from certain circles of the International Labour Organization in favor of a wage-led growth strategy. However, if the problem is one of competitiveness, it would follow that a reversal of the cumulative mechanism that caused the problem would require high wage growth for, say, Germany, but some form of continued wage stagnation for the workers of the GIIPS countries, who have already taken such a beating since the global financial crisis. In some ways, the difference between the neoclassical solution and the heterodox proposal is not one of substance but merely one of degree and intensity of adjustment of relative unit labor costs (ULCs). In fact, as shown in Figure 6, describing the gap in ULC growth rates for the period prior to and following the global financial crisis, the growth of ULCs in the GIIPS countries did exceed continually that of Germany (our reference line) and then witnessed a sharp reversal after 2008. On the one hand, as can be seen from the evolution of the current-account balances in Figure 7, there was a significant improvement in the current-account balances of the GIIPS countries, even though most remained in the red. On the other hand, Germany's current-account position steadily improved, thanks perhaps mostly to the higher growth of demand from the rest of the world, despite the broadly negative labor-cost growth turning in favor of the GIIPS countries. Hence what seems evident from this is that, if wage deflation in some of the GIIPS countries, such as Greece, does not fully turn around the current-account balance, the outcome would probably be no more likely as an effective policy if wages were merely to rise more quickly in Germany while stagnating in the periphery. Prima facie it would seem from the recent experience of the GIIPS countries that it would take more than merely this sort of incomes policy to solve the eurozone crisis.

Indeed, as emphasized by Storm/Naastepad (2016), the argument that adjustment of relative ULCs as a solution to the competitiveness problem via wage changes is somewhat crude and problematic because it narrowly looks only at wage costs. There is also productivity and non-price technological competitiveness that matters. The neoclassical solution of austerity would hardly get firms to invest in more productive and technologically 


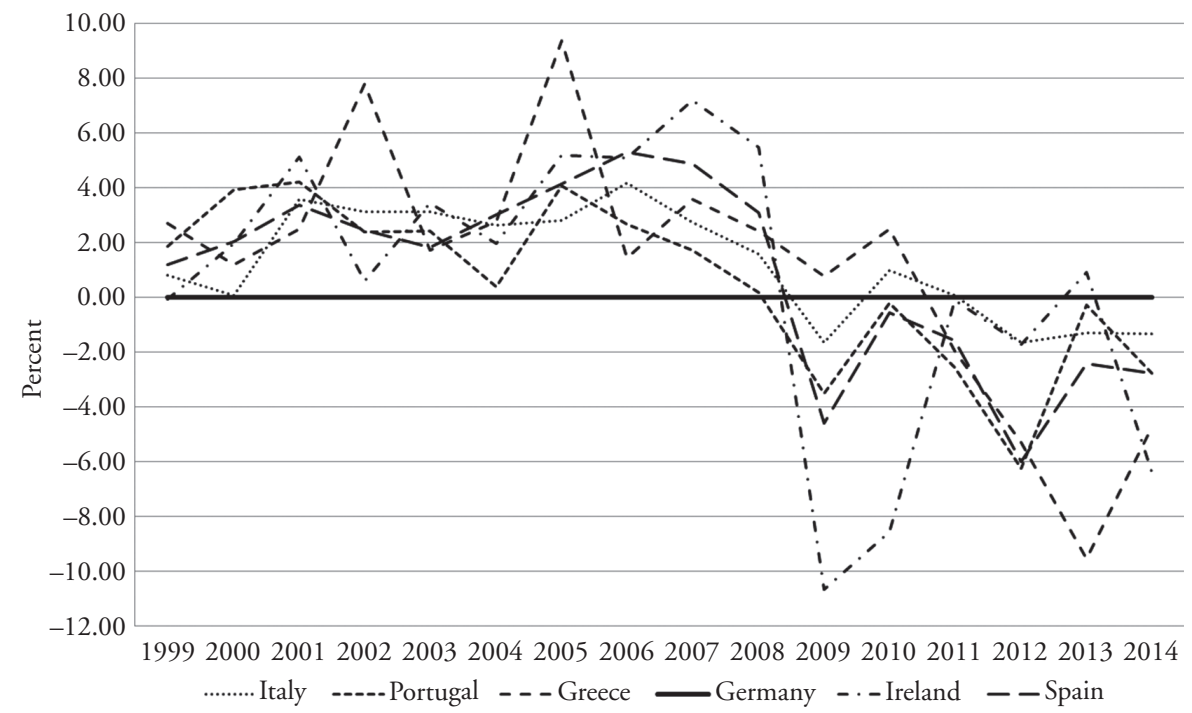

Source: OECD (https://data.oecd.org/lprdty/unit-labour-costs.htm).

Figure 6 Growth-rate spread in unit labor costs (with Germany as reference), 1999-2014

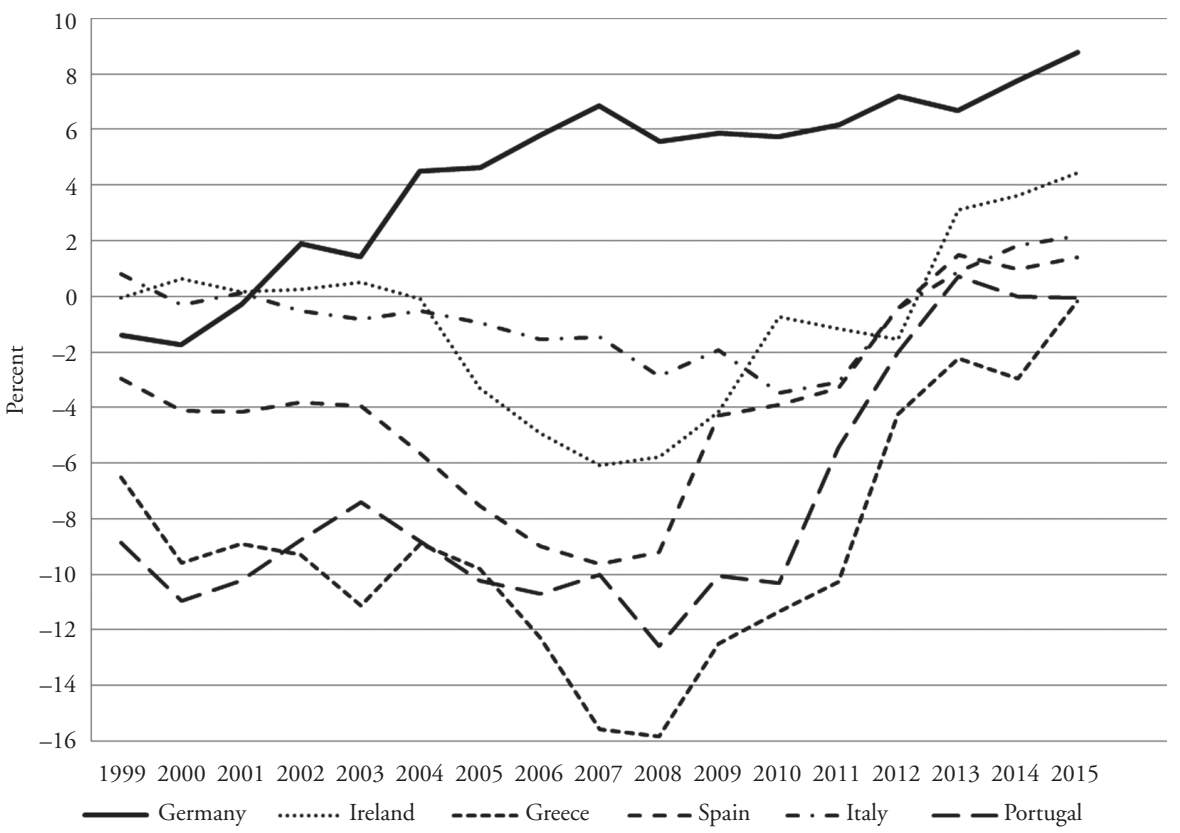

Source: AMECO (http://ec.europa.eu/economy_finance/ameco/user/serie/SelectSerie.cfm), Series Code: UBCA.

Figure 7 Current-account balances, selected countries of the eurozone, 1999-2015 
sophisticated activities in an environment in which overall demand is collapsing, as happened in the GIIPS countries in accordance with Verdoorn's law. What one would need are massive investments in the GIIPS countries, but that would not happen in a state of stagnant economic growth. Conversely, high wage growth may well stimulate greater productivity growth in Germany that would be better able to offset the growth in wages. Hence, a policy of both expanding demand and wage growth in the core countries could probably further reinforce the cleavage in non-price competition that exists between the latter countries and the periphery.

Finally, the wage policy argument may well be a solution in search of a problem. The problem in the eurozone since 2010 is one of financial imbalances generating problems of sovereign risk. Why should trade imbalances necessarily trigger financial imbalances? In a monetary union such as Canada and the United States, there will always be private-sector trade imbalances across regions. Hence, if a region such as Québec runs a trade deficit with a region like Alberta in Canada, all that would happen would be that Québécois assets would slowly be transferred financially to Albertans. As pointed out by Lavoie (2015b), this would not create a 'balance of payments' problem because there would be redistribution of assets denominated in that single currency, and it would not even necessarily lead to changing interest spreads between the two regions in a union. A balance-of-payments problem would only arise in a world of fixed or pegged exchange rates. For this reason, German mercantilism, no more than the simple fiscal profligacy argument, cannot properly explain the eurozone crisis.

\section{WHAT THEN IS THE EUROZONE CRISIS REALLY ALL ABOUT?}

As someone who believes that institutions matter a great deal, I wish to argue that I side strongly with those who have put forth the view that the problem with the EMU is one of 'faulty design' with an inherent deflationary bias. The precise structure was intentionally shaped from its inception to suppress within the whole eurozone significant wage growth and prevent strong public spending for macroeconomic stabilization (Parguez 2016). In that sense, the multitude of rules stipulated in the various eurozone treatises, since Maastricht in 1992, are there not because they are indispensable to the proper functioning of some ideal monetary union, but because they were designed to control the behavior of various economic agents in order to prevent 'excessive' wage growth and public spending. In opposition to the upside-down world of neoclassical economics, most heterodox economists nowadays would argue that such solid wage growth and high public spending are not in themselves the source of the problem but actually may be needed in the current context, especially in the core countries, for a more effective overall resolution of the crisis.

It is well understood within heterodox circles that the euro was designed as stateless money. Its institutional base, upon which it was founded, was designed to prevent national governments from relying on the supranational monetary authorities to eliminate problems of sovereign risk that come from building up public debt denominated in a currency that is not under national control (Parguez 1999; Kelton/Wray 2009; Lucarelli 2015; Seccareccia/Correa 2017). These institutions matter a great deal in the sense originally described by institutionalist economists going back to Thorstein Veblen (1899). As the social creation of what are generally accepted habits of thought, the actions of individuals behind these institutions, who abide by the rules of behavior that are specific to these institutional structures and who are constrained by economic agents' own cognitive limits, matter even more. This is because institutions, as social constructs, cannot be conceived as one would, for instance, a physical structure that exists independently of human 
action or conduct. To appreciate the importance of this in understanding what really happened in triggering the eurozone crisis, I would like to bring to the attention of the reader a short but important episode in the history of the eurozone. During that historical episode, procedural rationality and herd behavior were all that mattered and that eventually led to a certain institutional adaptation that mainstream writers seem to be incapable of understanding well. The experience of the eurozone during that short interval, coinciding with the global financial crisis from the end of 2008 to the beginning of 2010 , advises that perhaps it is possible to avoid crises as long as countries conduct expansionary Keynesian macroeconomic policy in tandem resulting from a common symmetric shock, as in 2008, and not in some desynchronized way. In short, bandwagon behavior without outliers is self-reinforcing, while perceived outliers generate fears and centrifugal forces cum cumulative processes.

As we have previously discussed and following O'Connell (2015) in terms of centerperiphery relations, let us continue to consider the eurozone as comprising two broad regions. There is a core region made up of more industrialized and financially more developed countries that include Germany, France, and the satellite countries of the North; and there is the periphery, which includes the less industrialized and less financially developed economies, primarily of Southern Europe, including Ireland (the GIIPS). After the reintegration of East and West Germany, reunified Germany came into the eurozone as a country of low inflation, low wage growth, and low growth especially in household spending. This can be easily substantiated in Figure 5, for instance, by a very flat housing market, when compared to some countries at the periphery that were experiencing much higher growth (see Figure 4). This is because all the GIIPS countries, which had been used to very high interest rates prior to the adoption of the euro under the EMS, quickly experienced a downward convergence of those interest rates, thanks to the currency union. Indeed, much as it had occurred in the US housing bubble, overwhelmingly local domestic banks, as well as perhaps even some German and French banks, which were better positioned to adopt the newly emerging pre-financial-crisis business model of banking, financed and encouraged speculative excesses and overinvestment in the real-estate market of these peripheral countries. Not all the GIIPS countries experienced the same private-sector growth, but noticeably all the GIIPS countries moved in a rather different direction to that of Germany. Even though there was strong growth in private spending in these countries, which, to a prudent financial institution, would signal higher risk for the national governments that might be stuck with the bail-out of financial institutions, interest rates converged in the downward direction throughout the eurozone until 2007. Consequently, despite the somewhat divergent evolution between Germany and the GIIPS countries, this did not disturb the financial markets and no one from the European political elite seriously took notice that there was a potential problem resulting from the nature of the perilous institutional structure constituting the eurozone.

Despite some ominous signs, this period of financial tranquility continued throughout the worst turmoil of the financial crisis from 2008 until early 2010, when most of the eurozone countries implemented important fiscal stimulus packages, just like many other countries internationally. As discussed earlier, both because of existing automatic stabilizers in place domestically and because of the discretionary fiscal stimulus packages, as well as important bank bail-outs in a number of countries, one witnesses tremendous spikes in deficit spending with public-debt ratios rising dramatically in all of these countries. During this short period, from the third quarter of 2008 to the end of 2009 , one observed the highest rise in the publicdebt ratios of all these countries in the history of the eurozone (as displayed in Figure 3 for both Germany and the GIIPS countries). Yet very little happened in the financial markets, when measured by changes in interest-rate spreads on long-term government bonds, which 
turned out to be only very mildly disturbed (see Figure $8 \mathrm{a}$ ). As one focuses carefully on that short period (see Figures $8 \mathrm{~b}$ and $8 \mathrm{c}$ for the GIIPS and Greece vis-à-vis the euro area), it took the financial markets at least a year during 2009 and even into 2010 to start to recognize the huge spike in the debt ratios that was supposedly to warn and foreshadow impending financial trouble. Indeed, as we can confirm from Figure 3, the public-debt ratios had risen greatly and had eventually plateaued by 2011 .

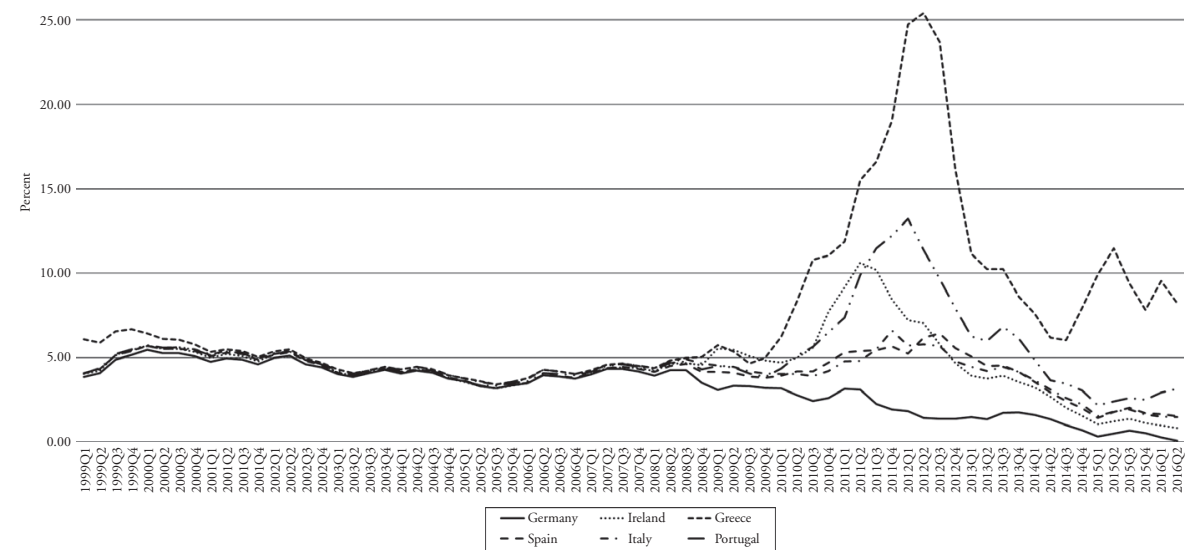

Source: Eurostat: EMU convergence criterion series - quarterly data [irt_lt_mcby_q], http://ec. europa.eu/eurostat/web/products-datasets/-/irt_lt_mcby_q.

Figure 8 a EMU convergence criterion bond yields, defined as central government bond yields on the secondary market with around 10 years' residual maturity, 1999-2016 (quarterly observations)

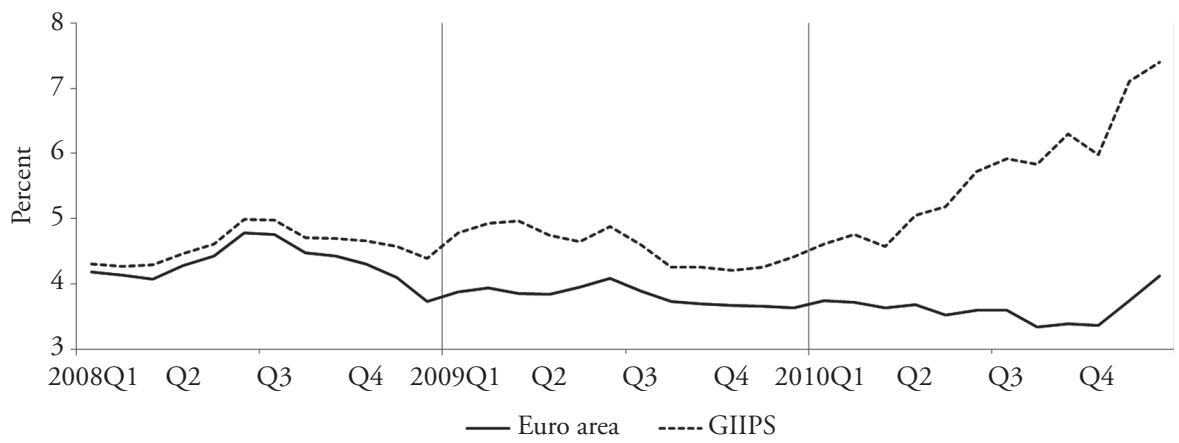

Source: Eurostat: EMU convergence criterion series - monthly data [irt_lt_mcby_m], http://ec. europa.eu/eurostat/web/products-datasets/-/irt_lt_mcby_m.

Figure $8 b$ Focus on the financial crisis period: interest-rate evolution of GIIPS countries vis$\dot{a}$-vis the euro area (monthly observations from January 2008 to December 2010) 


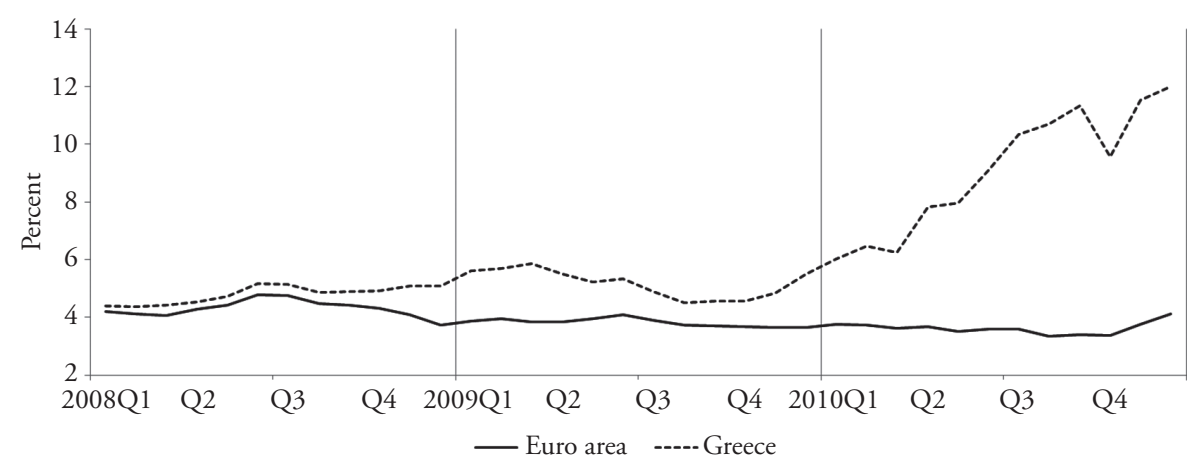

Source: Eurostat: EMU convergence criterion series - monthly data [irt_lt_mcby_m], http://ec. europa.eu/eurostat/web/products-datasets/-/irt_lt_mcby_m.

Figure $8 c$ Focus on the financial crisis period: interest-rate evolution of Greece vis-à-vis the euro area (monthly observations from January 2008 to December 2010)

Some would see this as an example of a 'market failure' in terms of financial markets misconstruing risk. Though no one could have easily predicted how the global financial shock in 2008 (emanating from the US epicenter of the financial crisis) would have affected the eurozone, many major banking and financial institutions in Europe would have known how indebted the GIIPS countries were. Many would also have known how much sovereign debt liability GIIPS governments would eventually be absorbing because of the bail-outs of these same banking institutions. After all, the latter knew how quickly the private sector had been building up unsustainable private debt during the previous era, since these financial institutions themselves had been their major lenders (for instance, in the housing bubble in the GIIPS countries), which then required massive bail-outs from national governments that quickly transformed the accumulated private debt into a public one. This was surely, according to the popular French expression, an open secret of Polichinelle. It should certainly not have taken another year (or even more) for the financial sector to recognize and then become frightened by the huge build-up of public debt that led eventually to the sharp rise in the interest spreads during 2010. This could hardly be considered an error of judgement or 'market failure' for the financial markets to start reacting massively only in early 2010 once the revelations of the so-called hidden debt of Greece appeared in the international media. Indeed, this hidden debt supposedly had been 'concealed' with the help of some of the same major financial players connected with such established multinational financial conglomerates as Goldman Sachs. Yet, it was already a year after the global financial crisis that the financial markets began eventually to start to downgrade extensively Greek sovereign debt, that is, after the election in Greece of a center-left PASOK government and the discovery of 'severe irregularities' in the previous accounting of the Greek public debt.

There are two possible explanations for this puzzling episode between 2008 and 2010 before the eurozone crisis, when the financial markets had accommodated the huge growth in public debt by vastly underestimating the risk associated with sovereign debt in Europe. After all, the main financial actors surely were aware that there existed a precise institutional structure delineated by the Maastricht Treaty of 1992 and the Stability and Growth Pact of 1997, with the political elites of Europe preaching fiscal responsibility by placing national governments on a legal and financial leash. This institutional structure was precisely put in place presumably to prevent this 'excessive' build-up of public debt 
that actually occurred on such a wide scale. Why then did the financial sector so easily finance this accumulation of debt that backfired only with the scandal surrounding the Greek debt in 2010?

The first of these explanations has to do with the Minskyan element of perceived risk during a period that followed a long episode of financial stability. As previously stated, it was certainly conceivable at the time to imagine that this huge private-sector debt in the periphery would be transformed into high-risk sovereign debt (Costâncio 2013). In the context of the 'New Fiscalism' and policy coordination of the period, most industrialized countries were also engaging in some form of fiscal pump-priming to combat the Great Recession in 2009 and to support the banking and financial sector. The herd effect of this policy emulation internationally made it certainly plausible that the growth that this would induce could spread within all the countries of the eurozone. Indeed, this would be more so than if only one single country engaged in deficit spending within the monetary union. Hence, the fears of pursuing 'Keynesianism in one country' did not really exist since one could expect that some, if not all, of this public spending could in due course come back in the form of increased revenues. These revenues would be forthcoming from increased overall growth, as long as others were pursuing in tandem similar policies to move the economy out of the recession and as long as this was seen as a 'temporary' measure to combat the recession. This may well be an important reason why the spreads widened only slightly throughout 2009 .

As can be observed from the above charts, it was only at the end of 2009 and during early 2010 that distrust began to prevail about the 'oversized' Greek debt. Once discordant behavior among policymakers took hold with their overt fears of default looming over most of the GIIPS countries, this quickly led to the unravelling of the fiscalist consensus that existed during late 2008 and throughout most of 2009. Only when the fiscal authorities began to move in reverse gear did interest rates explode and the financial markets begin to punish the weakest links, resulting in a significant widening of interest spreads for the post-2009 period. By early 2010, there was a general awakening of the financial markets to the fact that, unlike countries such as the United States and Japan, which have their own sovereign currencies, the countries of the eurozone were merely 'euroized' regimes, caught in a financial lobster trap as mere users of a currency. Moreover, directly related to this wakening to the prospect of these governments potentially defaulting on their debt, there was the recognition that certain eurozone countries could leave the EMU altogether (the so-called Grexit strategy). This further intensified concern about redenomination risk pertaining to the uncertainties surrounding the legal application of the lex monetae principle, that is, the juridical problem arising in the eventuality of full exit from the eurozone with regard to whether payment obligations would continue in euros or in the new sovereign currency of a departing member state. ${ }^{1}$

A second, and possibly more murky, reason that could also partly explain this particular phenomenon at the time of the global financial crisis of 2008-2009 might well pertain to the self-interest behavior of the banking and financial sector itself. The banks would have had hardly any desire or private interest in generating panic in the bonds markets about sovereign debt that would have meant raising the interest spreads to such high levels, as they were eventually to do after 2009-2010. Given the pressures for a banking bail-out in countries such as Ireland and Spain (because of the collapse of their housing markets), the banks needed the national governments' financial support to pull them out of potential bankruptcy, since some of the banks themselves did not know the precise extent of their own overall vulnerability during the thick of the financial crisis. Why would the banks want to put political pressure on policymakers in the GIIPS countries by encouraging

1. I am grateful to one of the two anonymous referees for suggesting this point. 
them not to go into debt (that is, by signaling higher risk that could result in the downgrading of government debt) when this could abort the possibility of their own bail-out? Surely, they had every interest in waiting until the national governments socialized their losses and saved the banks from insolvency. While this questionable/shadowy behavior certainly cannot be excluded, what is evident is that the expected link between those interest spreads and growing public-sector indebtedness in the eurozone did not materialize until after a very significant and somewhat bewildering time-lag of as much as a year.

While it would be difficult to brush off this second explanation for the behavior of the spreads during 2008-2009, one would like to think that it was most likely a mixture of the first and second explanations that can explain what actually happened at the time. To the extent that the first explanation holds more sway, the experience during the worldwide financial crisis would suggest that, as long as all countries seek to implement a fiscal policy expansion simultaneously, it would be possible to implement a Keynesian expansion with little effect on (or threats from) the financial markets, even under the institutional structure of the eurozone. This experience may well have been unique historically and may not actually be replicated or repeated in the prospective sense; but, retrospectively, the mere fact that it happened lends weight to the importance of how economic actors move collectively in conditioning their behavior within any given institutional structure of the type set out in the EMU architectural landscape.

In addition, it was not the recognition of large amounts of private toxic assets (once the bubble burst in 2008) in such countries as Ireland and Spain, but the fact that this had to be absorbed by their national governments as unproductive public debt that sustained the crisis. To use a Parguezian expression, it was not the 'good deficits' of the fiscal stimulus of 2008-2009 that triggered negative reaction from the financial markets, but the 'bad deficits,' as governments absorbed private toxic assets held in the banks' balance sheets (Parguez 2013). Hence, it was not the public spending on, say, public investments to stimulate growth that did the damage, but the recognition or perception that the emperor had no clothes once these countries' public-debt ratios rose, with governments finding themselves in an untenable situation of holding 'bad' debt. These bad debts then tended to rise dramatically once interest rates rose quickly, as in a Domar-type scenario with the compounding effect of real interest rates rising and real GDP growth plummeting.

This perception of bad debt became so widespread in 2010-2011 that, even when the former governor of the ECB, Jean-Claude Trichet, responded with the initial round of purchases (through the central bank's Securities Market Program) of these government bonds in the secondary markets, the reaction of the ECB was inadequate at the time to counteract the widely held perception. In 2010-2011, the political support for a stronger commitment by the ECB of a quasi-permanent change in its role was not yet there. As will be discussed below, the most significant turning point in the spreads came in 2012. The current governor, Mario Draghi, made it very clear to the financial markets that the ECB was de facto acquiring a new institutional role in the holding and managing of government sovereign debt, which until then had neither been understood by the ECB authorities nor sufficiently asserted and communicated to the principal protagonists in the financial markets.

\section{INSTITUTIONAL ADAPTATION IN RECENT TIMES: LEARNING FROM THIS HISTORICAL EXPERIENCE}

Fiscal austerity since 2010 has led to a reversal of the GIIPS competitiveness position and an improvement in their current-account balances (as displayed in Figures 6 and 7). However, interest rates did not begin to plateau until the ECB vowed to intervene systematically and 
massively in buying sovereign debt in the secondary bond market. Indeed, the remedy to backstop and prevent the financial fallout and default of some of the GIIPS countries required ultimately that the ECB declare itself in July 2012 to stand ready to purchase government securities, with full financial market sterilization, as needed through Outright Monetary Transactions (OMT). Yet, to replace the ECB original bond purchases program (via its Securities Market Program (SMP)) after 2012, the support took many other forms as well. For instance, it took the form of direct rescue loans such as the European Financial Stability Facility (EPSF), the European Financial Stability Mechanism (EFSM), the European Stability Mechanism (ESM) by 2013, and even support from the IMF. However, these were all Band-Aid solutions of a largely contradictory nature. These funding agencies would provide the various loans and financial support only if national governments agreed to further austerity, which at the end made it perhaps even more difficult for some of the most vulnerable members of the GIIPS countries, especially Greece, to generate the domestic growth needed to meet their debt service requirements.

Since the beginning of 2015, the ECB took further steps to implement a policy of quantitative easing $(\mathrm{QE})$ in the form of unsterilized asset purchases in the secondary bond market. Much has been written about the effects of QE in countries such as the US and Japan. As shown in some previous work (Lavoie/Seccareccia 2012; Seccareccia 2017), QE cannot generate spending growth except, at best indirectly, through its effects on the level of central bank interest rates and by remolding the shape of the yield curve. It cannot directly stimulate private spending along traditional quantity theory reasoning. However, one other important positive effect of QE in the eurozone is that, by sustaining bond prices and very low yields on government securities, the ECB has enabled more fiscal space to eurozone governments even without direct purchases of government securities on the primary market, that is, without contravening eurozone treaties. In a clumsy and byzantine way, the ECB is now taking on an institutional role behind the scene as a sort of 'fiscal complement' of last resort that no previous treaties had ever considered or approved. De facto (but not de jure), the ECB no longer acts as if it is completely removed from national government financing of deficits and debt. It will systematically respond to crisis needs (via financial intervention) through its actions in the secondary bond markets, as it has been doing, since the beginning of the eurozone crisis. However, it is doing so only with the extremely limited tools that are available to a central bank and without the legitimacy that a central fiscal authority would command in gaining access to central bank financing, as in most non-dollarized countries possessing their own sovereign currency.

An obvious lesson from all this is that a modern monetary market economy founded on the fundamental separation between money and the state is dysfunctional and cries out for a fiscal authority that can implement macroeconomic stabilization policies, which even the current governor of the ECB implicitly recognized in his famous Jackson Hole speech in August 2014 (Draghi 2014). In the short history of the eurozone, we have seen that, whenever the EMU is confronted with a serious shock to the system, as during 2008-2009, it has been able temporarily to behave as if this constraint does not exist, only to be faced in 2010 with the challenge of a still greater and deeper crisis. The monetary authorities have been tinkering a great deal with the way in which they conduct monetary policy since 2012. These authorities are now offering greater monetary souplesse to the national fiscal authorities, but without changing the essentially dysfunctional nature of the eurozone structure. In some recent studies, such as that of Juncker et al. (2015), there is a clear recognition of the need to conduct counter-cyclical fiscal policy, which for most EMU countries remains painfully pro-cyclical. While these official reports still are concerned with the need for fiscal discipline and better compliance with the common fiscal rules, there is also reference to a fiscal stabilization function that would favor automatic 
mechanisms for counter-cyclical stabilization. For instance, Juncker et al. (2015: 14) reject outright discretionary fiscal stabilization; instead, they argue: 'The objective of automatic stabilisation at the euro area level would not be to actively fine-tune the economic cycle at euro area level. Instead, it should improve the cushioning of large macroeconomic shocks and thereby make EMU overall more resilient.'

The same emerges from the more recent reports from the European Commission in support of deep integration by 2025 through a framework of 'fiscal stabilization' that would avoid 'pro-cyclical' fiscal policies (European Commission 2017: 15). Once again, these European policymakers do not give themselves any substantive tools to achieve their goal at the eurozone level other than merely tinkering around the edges, as reflected in their suggestions for some strengthening of public investment over the business cycle and perhaps an EMU-wide addon unemployment 'reinsurance' scheme. There is, therefore, a growing recognition of the necessity for the conduct of counter-cyclical macroeconomic policy within the eurozone because, without it, the outcome is permanent austerity that will continue to increase disparities both socially and regionally. However, European policymakers remain stuck in an institutional box where macroeconomic stabilization policy of neither an automatic nor a discretionary nature can find legitimacy, because fundamentally the problem is a political one. Once the political problem of still deeper or shallower integration is settled, policy options are certainly available with or without the euro (Ehnts 2017: 193-201).

\section{REFERENCES}

Asensio, A. (2013): Coping with European public debt problem: the desperate new 'Growth Pact' of 2012 and its aftermath, in: International Journal of Political Economy, 42(2), 46-62.

Auerback, M. (2010/2011): A 'United States of Europe' or full exit from the euro?, in: International Journal of Political Economy, 39(4), 87-102.

Baldwin, R., Giavazzi, F. (2015): The Eurozone crisis: a consensus view of the causes and a few possible solutions, 7 September, URL: http://voxeu.org/article/eurozone-crisis-consensus-viewcauses-and-few-possible-solutions.

Brancaccio, E. (2012): Current account imbalances, the Eurozone crisis, and a proposal for a 'European wage standard,' in: International Journal of Political Economy, 41(1), 47-65.

Brodzicki, T. (2012): On optimality or non-optimality of the Eurozone, Working paper no 1, February, Uniwersytet Gdanski, Analizy/Opracowania, URL: http://gnu.univ.gda.pl/-keie/aio25.pdf.

Calmfors, L., Corsetti, G., Hassler, J., Saint-Paul, G., Sinn, H.-W., Sturm, J.E., Valentinyi, A., Vives, X. (2012): The European balance-of-payments problem, in: EEAG Report on the European Economy 2012, Munich: CESifo Group Munich, ch. 2, 57-82.

Carlberg, M. (1999): European Monetary Union: Theory, Evidence, and Policy, Heidelberg: PhysicaVerlag.

Carlberg, M. (2001): An Economic Analysis of Monetary Union, Berlin: Springer-Verlag.

Carlberg, M. (2006): Monetary and Fiscal Policies in the Euro Area, Berlin: Springer.

Cesaratto, S. (2015): Balance of payments or monetary sovereignty? In search of the EMU's original sin: comments on Marc Lavoie's 'The Eurozone: similarities to and differences from Keynes's plan,' in: International Journal of Political Economy, 44(2), 142-156.

Cesaratto, S. (2017): Alternative interpretations of a stateless currency crisis, in: Cambridge Journal of Economics, 1-22, doi: 10.1093/cje/bew065.

Cesaratto, S., Stirati, A. (2010/2011): Germany and the European and global crises, in: International Journal of Political Economy, 39(4), 56-86.

Constâncio, V. (2013): The European crisis and the role of the financial system, speech delivered by Vítor Constâncio, vice-president of the ECB, at the Bank of Greece conference on The Crisis in the Euro Area, Athens, 23 May, URL: http://www.ecb.europa.eu/press/key/date/2013/html/ sp130523_1.en.html. 
Draghi, M. (2014): Unemployment in the euro area, speech by Mario Draghi, president of the ECB, Annual Central Bank Symposium in Jackson Hole, WY, 22 August, URL: https://www. ecb.europa.eu/press/key/date/2014/html/sp140822.en.html.

Ehnts, D.H. (2017): Modern Monetary Theory and European Macroeconomics, London: Routledge.

European Commission (2017): Reflection paper on the deepening of the Economic and Monetary Union, Brussels: European Commission, 31 May, URL: https://ec.europa.eu/commission/sites/ beta-political/files/reflection-paper-emu_en.pdf.

Flassbeck, H., Lapavitsas, C. (2013): The Systemic Crisis of the Euro: True Causes and Effective Therapies, Berlin: Rosa-Luxemburg-Stiftung.

Frankel, J.A., Rose, A.K. (1998): The endogeneity of the optimum currency area criteria, in: Economic Journal, 108(449), 1009-1025.

Hein, E., Truger, A. (2014): Fiscal policy and rebalancing in the euro area: a critique of the German debt brake from a post-Keynesian perspective, in: Panoeconomicus, 61(1), 21-38.

Juncker, J.C. (in cooperation with Tusk, D., Dijssebloem, J., Draghi, M., Schulz, M.) (2015): The Five Presidents' Report: Completing Europe's Economic and Monetary Union, Brussels: European Commission, 22 June, URL: https://ec.europa.eu/commission/sites/beta-political/ files/5-presidents-report_en.pdf.

Kelton, S.A., Wray, L.R. (2009): Can Euroland survive?, Public Policy Brief No 106, November, URL: http://www.levyinstitute.org/pubs/ppb_106.pdf.

Koo, R. (2014): The Escape from Balance Sheet Recession and the QE 'Trap', Report, Nomura Research Institute, Tokyo, November, URL: http://www.eunews.it/docs/koo.pdf.

Lavoie, M. (2015a): The Eurozone: similarities to or differences from Keynes's plan, in: International Journal of Political Economy, 44(1), 3-17.

Lavoie, M. (2015b): The Eurozone crisis: a balance-of-payments problem or a crisis due to a flawed monetary design? A reply to Sergio Cesaratto, in: International Journal of Political Economy, 44(2), 157-160.

Lavoie, M., Seccareccia, M. (2012): Monetary policy in a period of financial chaos: the political economy of the Bank of Canada in extraordinary times, in: Rochon, L-P., Olawoye, S.Y. (eds), Monetary Policy and Central Banking: New Directions in Post-Keynesian Theory, Cheltenham, UK and Northampton, MA: Edward Elgar, 166-189.

Lucarelli, B. (2015): The euro: a Chartalist critique, in: International Journal of Political Economy, 44(1), 18-31.

O'Connell, A. (2015): European crisis: a new tale of center-periphery relations in the world of financial liberalization/globalization? in: International Journal of Political Economy, 44(3), 174-195.

Parguez, A. (1999): The expected failure of the European Economic and Monetary Union: a false money against the real economy, in: Eastern Economic Journal, 25(1), 63-76.

Parguez, A. (2013): Le vere regole di una buona amministrazione della finanza, in: Parguez, A., Dallo Stato Sociale allo Stato Predatore: La Storia Nascosta dell'Eurozona ... e come Sfuggire alla Corsa nel Precipizio, Roma: Edizioni Andromeda, 103-122.

Parguez, A. (2016): Economic theories of social order and the origins of the euro, in: International Journal of Political Economy, 45(1), 2-16.

Parguez, A., Seccareccia, M., Gnos, C. (2003): The theory and practice of European monetary integration: lessons for North America, in: Rochon, L.-P., Seccareccia, M. (eds), Dollarization: Lessons from Europe and the Americas, London and New York: Routledge, 48-69.

Seccareccia, M. (2012): Understanding fiscal policy and the New Fiscalism: a Canadian perspective, in: International Journal of Political Economy, 41(2), 61-81.

Seccareccia, M. (2017): Which vested interests do central banks really serve? Understanding central bank policy since the global financial crisis, in: Journal of Economic Issues, 51(2), 341-350.

Seccareccia, M., Correa. E. (2017): Supra-national money and the euro crisis: lessons from Karl Polanyi, in: Forum for Social Economics, 46(3), 252-274.

Seccareccia, M., Lequain, M. (2006): What can we learn from the EMU model? Lessons for Canada and Britain, in: Current Politics and Economics of Europe, 17(2), 289-315.

Simonazzi, A., Ginzburg, A., Nocella, G. (2013): Economic relations between Germany and southern Europe, in: Cambridge Journal of Economics, 37(3), 653-675. 
Sinn, H.-W. (2014): Austerity, growth and inflation: remarks on the Eurozone's unresolved competitiveness problem, in: World Economy, 37(1), 1-13.

Stiglitz, J.E. (2014): Can the euro be saved? An analysis of the future of the currency union, in: Rivista di Politica Economica, 3, 7-42.

Stiglitz, J.E. (2016): The Euro: How a Common Currency Threatens the Future of Europe, New York: W.W. Norton.

Storm, S., Naastepad, C.W.M. (2016): Myths, mix-ups, and mishandlings: understanding the eurozone crisis, in: International Journal of Political Economy, 45(1), 46-71.

Truger, A. (2013): Austerity in the euro area: the sad state of economic policy in Germany and the EU, in: European Journal of Economics and Economic Policies: Intervention, 10(2), 158-174.

Veblen, T. (1899): The Theory of the Leisure Class: An Economic Study of Institutions, New York: B.W. Huebsch. 